\title{
Examination of Fund Flow Management with Reference to Jemi Cluster
}

\author{
Magdalene Peter, S.Fabiyola Kavitha, Geetha C
}

\begin{abstract}
The endeavor titled "A Study on Fund stream the authorities" drove in Jemi Cluster to look into the demonstration of a touch of room or store isn't considered. The goal of this appraisal is to pick the operational ability of the affiliation utilizing degrees, to understand the developments in spending report as far back as 5 years by utilizing working capital explanation, to figure the future changes utilizing the model assessment, to lead store stream articulation for 2013-2016, to perceive the financial quality and insufficiency that the affiliation may have and to isolate the relationship between Net bit of leeway and EPS utilizing Correlation assessment. The degree for this task is that the evaluation covers the majority of the bits of current resources and current liabilities for the year 2013-2016, the assessment besides manages the different degrees permitted in the association, and the working capital is one of the dynamic and essential bits of the business activity. [1],[3],[5] This endeavor urges the association to achieve the objectives by using extent assessment and after that connecting at finishes, which are basic to appreciate the capability/inefficiency of Cash. It urges the association to look at whether the cash required to meet out the present liabilities is kept up at an average level that shows the association seeks after an ordinary technique. [7],[ 9] ,[11]
\end{abstract}

The firm needs to put enough resources in current asset for creating bargains. Current asset are required in light of the way that arrangements don't change over into cash rapidly. There is reliably a working cycle drawn in with the difference in offers into cash.

Keywords : flow analysis,cash,management

\section{INTRODUCTION}

The net of all money inflows and floods all through different cash related resources. Spare stream is generally assessed on a month to month or quarterly reason. The demonstration of a good position or store isn't considered, basically offer recoveries (outpourings) and offer buys (inflows). [8],[ 10] ,[12]

Net inflows benefit for managers to contribute, which hypothetically makes energy for affirmations, for example, stocks and securities. Inspectors and market operators watch store streams to check budgetary star supposition inside

Revised Manuscript Received on July 22, 2019.

* Correspondence Author

Magdalene Peter, Department of MBA, Bharath Institute of Higher Education and Research, Tamilnadu, India. Email: magdalene.bsb@gmail.com Dr.S.Fabiyola Kavitha , Department of MBA, Bharath Institute of Higher Education and Research, Tamilnadu, India. Email: fabiyolakavitha@gmail.com

Geetha C, Department of CSE, Bharath Institute of Higher Education and Research, Tamilnadu, India.. Email: gitakannan.2010@gmail.com unequivocal resource classes, regions, or for the market with everything considered. For example, if net hold streams for insurances assets during a given month is negative by a titanic total, this would hail wide based analysis over the fixed-pay markets. [2 ],[4],[6]

\section{OBJECTIVES}

A. Primary Objective

To study the fund flow analysis of Jemi Cluster

B. Secondary Objectives

- To decide the operational productivity of the organization utilizing proportions [25],[27],[29]

- To know the progressions in fiscal summary for as long as 3 years by utilizing working capital proclamation

- To figure the future changes utilizing the pattern investigation

- To direct reserve stream explanation for 2013-2016

- To distinguish the money related quality and shortcoming that the organization may have.

- To examine the connection between Net benefit and EPS utilizing Correlation investigation

\section{DATA ANALYSIS AND INTERPRETATION}

\section{Table:1 SCHEDULE OF CHANGES IN WORKING CAPITAL FOR THE YEAR ENDED 2014-2015}

\begin{tabular}{|c|c|c|c|c|}
\hline PARTICULARS & $\begin{array}{l}2014 \\
\text { AMOUNT }\end{array}$ & $\begin{array}{l}2015 \\
\text { AMOUNT }\end{array}$ & $\begin{array}{l}\text { INCREASE } \\
\text { AMOUNT }\end{array}$ & $\begin{array}{l}\text { DECREASE } \\
\text { AMOUNT }\end{array}$ \\
\hline \multicolumn{5}{|l|}{ CURRENT ASSETS: } \\
\hline Cash \& Balances & 61290.87 & 94395.50 & & 33104.6 \\
\hline Balance with Company's & 34892.98 & 28478.65 & 6414.33 & \\
\hline Advances & 631914.15 & 756719.45 & & 124805 \\
\hline CURRENT & 728098 & $\mathbf{8 7 9 5 9 3 . 6}$ & & \\
\hline CURRENT & & & & \\
\hline Liabilities & 80336.70 & 105248.39 & 24911.69 & \\
\hline TOTAL CURRENT & 80336.70 & 105248.39 & & \\
\hline WORKING & 647761.30 & 774345.21 & & \\
\hline \multirow{2}{*}{\multicolumn{3}{|c|}{$\begin{array}{l}\text { TOTAL } \\
\text { NET CHANGE IN WC }\end{array}$}} & 31326.02 & 157909.6 \\
\hline & & & & 126583.58 \\
\hline
\end{tabular}


Examination of Fund Flow Management with Reference to Jemi Cluster

Table:2 Non-Current Accounts

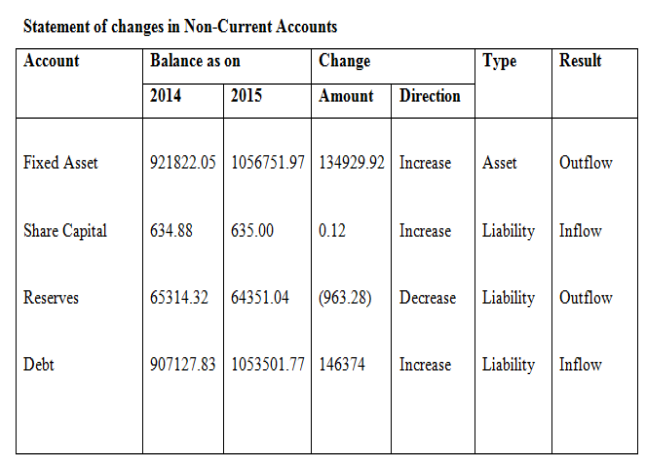

Table:3 Calculation Of Fund Flow Statement

\begin{tabular}{|c|c|c|c|}
\hline Sources/ Inflow of funds & RS & $\begin{array}{l}\text { Application/ Outflow of } \\
\text { funds }\end{array}$ & Rs \\
\hline Debt & 146374 & Fixed Asset & 134929.92 \\
\hline Share Capital & 0.12 & Reserves & 963.28 \\
\hline Funds from Operation & 126583.58 & & \\
\hline Increase in WC & 137064.50 & & \\
\hline & 272957.70 & & 272957.70 \\
\hline
\end{tabular}

Table:4 SCHEDULE OF CHANGES IN WORKING

\section{CAPITAL FOR THE YEAR ENDED 2015-2016}

\begin{tabular}{|l|l|l|l|l|}
\hline PARTICULARS & $\begin{array}{l}\text { 2015 } \\
\text { AMOUNT } \\
\text { Rs. }\end{array}$ & $\begin{array}{l}2016 \\
\text { AMOUNT } \\
\text { Rs. }\end{array}$ & $\begin{array}{l}\text { INCREAS } \\
\text { F } \\
\text { AMOUNT } \\
\text { Rs. }\end{array}$ & $\begin{array}{l}\text { DECREASE } \\
\text { AMOUNT } \\
\text { Rs. }\end{array}$ \\
\hline CURRENT ASSETS: & & & & \\
\hline Cash \& Balances & 94395.50 & 54075.94 & & 40319.56 \\
\hline Balance with Company's & 28478.65 & 43087.23 & 14608.60 & \\
\hline Advances & 756719.45 & 867578.89 & 110859 & \\
\hline $\begin{array}{l}\text { TOTAL CURRENT } \\
\text { ASSETS }\end{array}$ & 879593.6 & 964742.06 & & \\
\hline $\begin{array}{l}\text { LESS: CURRENT } \\
\text { LIABILITIES }\end{array}$ & & & & \\
\hline $\begin{array}{l}\text { Other Lisbilitis \& } \\
\text { Provisions }\end{array}$ & 105248.39 & 80915.09 & 24333.30 & \\
\hline $\begin{array}{l}\text { TOTAL CURRENT } \\
\text { LIABILITIES }\end{array}$ & 105248.39 & 80915.09 & & \\
\hline $\begin{array}{l}\text { NET WORKING } \\
\text { CAPITAL }\end{array}$ & 774345.21 & & & 109481.34 \\
\hline \begin{tabular}{l} 
TOTAL \\
\hline NET CHANGE IN WC
\end{tabular} & & & \\
\hline
\end{tabular}

Table:5 Statement of changes in Non-Current Accounts

\begin{tabular}{|c|c|c|c|c|c|c|}
\hline \multirow{2}{*}{ Account } & \multicolumn{2}{|c|}{ Balance as on } & \multicolumn{2}{|l|}{ Change } & \multirow{2}{*}{ Type } & \multirow{2}{*}{ Result } \\
\hline & 2015 & 2016 & Amount & Direction & & \\
\hline Fixed & 1056751.97 & 1184910.37 & 128158.40 & Increase & Asset & Outflow \\
\hline & 635.00 & 671.04 & 36.04 & Increase & Liability & Inflow \\
\hline Share & & & & & & \\
\hline Cspital & 64351.04 & $83,280.16$ & 18929.12 & Increase & Liability & Inflow \\
\hline Reserves & 1053501.77 & $1,170,652.93$ & 117151.16 & Increase & Liability & Inflow \\
\hline Debt & & & & & & \\
\hline
\end{tabular}

Table:6 CALCULATION OF FUND FLOW STATEMENT

\begin{tabular}{|l|l|l|l|}
\hline $\begin{array}{l}\text { Sources/ Inflow of } \\
\text { funds }\end{array}$ & RS & $\begin{array}{l}\text { Application/ Outflow } \\
\text { of funds }\end{array}$ & $\mathrm{Rs}$ \\
\hline Share Cspital & 36.04 & Decrease in WC & 117439.26 \\
Reserves & 18929.12 & Fixed Asset & 128158.40 \\
Debt & 117151.16 & & \\
\hline $\begin{array}{l}\text { Funds } \\
\text { Operation }\end{array}$ & 109481.34 & & 245597.66 \\
\hline
\end{tabular}

Table:7 CORRELATION CALCULATION OF NET PROFIT AND EPS

\begin{tabular}{|l|l|l|l|l|l|}
\hline Year & $\begin{array}{l}\text { NET PROFIT } \\
(\mathrm{X})\end{array}$ & $\mathrm{X}^{2}$ & EPS(Y) & $\mathrm{Y}^{2}$ & $\mathrm{XY}$ \\
\hline 2013 & 6729.46 & 29357.39 & 106.56 & 11355.0336 & 717091.3 \\
\hline 2013 & 9121.57 & 26425.75 & 143.67 & 20641.0689 & 1310496 \\
\hline 2013 & 9166.39 & 233462.91 & 144.37 & 20842.6969 & 1323352 \\
\hline 2015 & 7370.69 & 266204.40 & 116.07 & 13472.2449 & 855516 \\
\hline 2016 & 11713.34 & 92695.89 & 174.15 & 30328.2225 & 2039878 \\
\hline$\Sigma \square=$ & 44101.45 & 404040781.8 & 684.82 & 96639.2668 & 30201555 \\
\hline & & & & C0RRELATION & 0.995787 \\
\hline
\end{tabular}




\section{RESULTS}

- The current year (2016) restrictive proportion is observed to be 0.06286 it is in an expanding position.

- The Standard Deviation for NP is 1735.12

- The standard deviation of Cash and friends parity is 17862.287

- There is a high level of connection between's Net benefit and EPS in light of the fact that the relationship esteem $(0.995787)$ is more than 0.05 . It gauges the closeness of connection between Net benefit and EPS and the two of them have a positive relationship.

- The current year(2016) return on investors value is expanded to 17.45

- In the year 2015 the Debt-value proportion is higher which implies that the organization is having a higher influence. [31],[33],[32]

- In the year 2016 the Fixed resource proportion is expanded to 0.0044 . This implies the organization's fixed resource position is acceptable [26],[28],[30]

- On the year 2016 the Return on Asset is higher. In this way higher estimations of profit for resources demonstrate that business is progressively beneficial

- The present year obligation to add up to resource proportion is expanded to $87.65 \%$ when contrasted with the earlier year $86.09 \%$.

\section{V.DISCUSSION}

1.There are differing generally difficulties that are looked by each relationship in the present focused condition and Jemi Cluster isn't any exception. To confront the present generally speaking inconveniences the HR division ought to be make to improve different limits among the agents astoundingly the luring aptitudes and having the standard preparing for the workers about different movements in the market. [19],[21],[23]

2. The current resources ought to be controlled considerably increasingly enough in order to evade pointless forestalling of capital that could be utilized for different purposes.

3. The Working Capital need is to be evaluated subject to the measures gushed by RBI [20],[22], [24]
4. The affiliation has kept up appropriate records showing full focal points, quantitative subtleties and courses of action of fixed resources are showed up for enormous things in the register, the associations during the year has driven an optional check in regard of fixed resources, which as we would see it is sensible, having thankfulness to the size of the affiliation and the likelihood of its favorable circumstances. [14],[ 16], [18]

\section{CONCLUSION}

The affiliation is performing unfathomably well due to the up wising in the general market looked for after by the private market. It is a top tier one with uncommon and creative contemplations and had faith in improving the majority of the districts of its activities. The affiliation has a not all that terrible liquidity position and does not concede its responsibility in certified money of the two its leasers and obliged individuals. The affiliation being commonly subject to the working capital working environments, it is keeping up bewildering association with their affiliations and their working capital association is all around adjusted. [13], [15] ,[17]

\section{REFERENCES}

1. G BharthVajan R., Ramachandran S.,Psychographic dimensions of training,2016,International Journal of Pharmacy and Technology,V-8,I-4,P-23727-23729

2. Balakrishnan P., Bharthvajan R.,A study on human resource planning in hospitals in Chennai City,2014,International Journal of Applied Engineering Research,V-9,I-22,P-7503-7507

3. Priyadarsini P., Bharthvajan R.,Role of emotional intelligence training programme in reducing the stress of the nurses,2014,International Journal of Applied Engineering Research,V-9,I-22,P-7411-7421

4. Kerinab Beenu G., Bharthvajan R.,Empirical analysis on the cosmetic buying behavior of young women in South India,2014,International Journal of Applied Engineering Research,V-9,I-22,P-7361-7366

5. Balakrishnan P., Bharthvajan R.,Whistling in the wind,2014,International Journal of Applied Engineering Research,V-9,I-22,P-7586-7593

6. Krishnan B., Peter M.,Health hazards of Indian Bpo employee-an alarming issue,2014,International Journal of Applied Engineering Research,V-9,I-22,P-7336-7341

7. Kerinab Beenu G.H., Peter M.,Role of insurance in economic development,2014,International Journal of Applied Engineering Research,V-9,I-22,P-7532-7539

8. Balakrishnan P., Peter M., Priyadarsini P.,Efficiency of safety measures for wellbeing of employees in manufacturing industry,2014,International Journal of Applied Engineering Research,V-9,I-22,P-7376-7382

9. Anbarasi M., Praveen Kumar S.,Online sales promotions of herbal products and its effectiveness towards tanisha.com,2019,Indian Journal of Public Health Research and Development,V-10,I-1,P-195-200

10. Anbarasi M., Praveen Kumar S., Various online marketing and promotions strategies to improve the validation towards the organic products in the pharmaceutical sectors,2019,Indian Journal of Public Health Research and Development,V-10,I-1,P-263-269

11. Loganathan R., Praveen Kumar S.,Grievance handling a key factor for solving issues of employees in an organization,2014,International Journal of Applied Engineering Research,V-9,I-22,P-7483-7491

12. Loganathan R., Praveen Kumar S.,Study on preference of private label brands in super and Hypermarkets, 2014,International Journal of Applied Engineering Research,V-9,I-22,P-7327-7335

13. Smitha M., Praveen Kumar S.,Understanding stress and its managementamong the nurses in Chennai city,2014,International Journal of Applied Engineering Research,V-9,I-22,P-7560-7565

14. Kerinab Beenu G.H., Praveen Kumar S.,A study on the investment behavior of Chennai investors in mutual fund schemes,2014,International Journal of Applied Engineering Research,V-9,I-22,P-7520-7525 


\section{Examination of Fund Flow Management with Reference to Jemi Cluster}

15. Loganathan R., Praveen Kumar S.,Retention strategies key for organizational productivity,2014,International Journal of Applied Engineering Research,V-9,I-22,P-7443-7447

16. Pavithra J., Ganesan M., Brindha G.,State wise analysis of microfinance sector in India,2016,International Journal of Pharmacy and Technology,V-8,I-4,P-23417-23432

17. Pavithra J., Ganesan M.,A comparative study on microfinance in India and abroad,2016,International Journal of Applied Business and Economic Research,V-14,I-8,P-5471-5476

18. Pavithra J., Ganesan M.,A study on awareness and impact of micro-financial schemes,2016,International Journal of Applied Business and Economic Research,V-14,I-8,P-5449-5460

19. Senthilmurugan P., Pavithra J.,Consumer preference towards organised retailing with reference to Big Bazaar,2014,International Journal of Applied Engineering Research,V-9,I-22,P-7469-7475

20. Senthilmurugan P., Pavithra J.,Implication of social media marketing in growing healthcare industry,2014,International Journal of Applied Engineering Research,V-9,I-22,P-7448-7456

21. Loganathan R., Pavithra J.,Consumer perception towards private label brand over other brands in super markets and hypermarkets,2014,International Journal of Applied Engineering Research,V-9,I-22,P-7355-7360

22. Kerinab Beenu G., Pavithra J.,Tradeâ€"off between liquidity and profitability in logistics industry,2014,International Journal of Applied Engineering Research,V-9,I-22,P-7398-7401

23. Kerinab Beenu G., Pavithra J.,A study on the prospective consumerâ€ $€^{\mathrm{TM}_{\mathrm{S}}}$ perception towards utility cars in Chennai city,2014,International Journal of Applied Engineering Research,V-9,I-22,P-7526-7531

24. Pavithra J., Dilli Babu P., Ambuli T.V.,A study on budgetary control at Maruti Service Masters, Chennai,2014,International Journal of Applied Business and Economic Research,V-12,I-2,P-151-161

25. Pavithra J., Dilli Babu P., Ambuli T.V.,A study on customer satisfaction of retro Garments Pvt Ltd, Chennai,2014,International Journal of Applied Business and Economic Research,V-12,I-2,P-381-391

26. Kerinab Beenu G.H., Pavithra J., Senthilmurugan P.,A study on the influence of promotional activities for TATA ARIA among consumers in Chennai,2014,International Journal of Applied Engineering Research,V-9,I-22,P-7572-7578

27. Vijayaragavan S.P.,An investigative expert that's general FBG sensors,International Journal of Mechanical Engineering and Technology,V-8,I-8,PP-1500-1505,Y-2017

28. Vijayaragavan S.P.,Equalization routing protocol for Wi-Fi sensor strategy,International Journal of Mechanical Engineering and Technology,V-8,I-8,PP-1662-1666,Y-2017

29. Karthik B., Kiran Kumar T.V.U., Vijayaragavan P., Bharath Kumaran E.,Design of a digital PLL using 0.35 $\hat{\mathrm{I}}^{1 / 4 \mathrm{~m}}$ CMOS technology,Middle East Journal of Scientific Research,V-18,I-12,PP-1803-1806,Y-2013

30. Kanniga E., Selvaramarathnam K., Sundararajan M.,Kandigital bike operating system,Middle - East Journal of Scientific Research,V

31. Jasmin M., Vigneshwaran T., Beulah Hemalatha S.,Design of power aware on chip embedded memory based FSM encoding in FPGA,International Journal of Applied Engineering Research,V-10,I-2,PP-4487-4496,Y-2015

32. Jasmin M.,Optimization techniques for low power VLSI circuits,Middle East Journal of Scientific Research,V-20,I-9,PP-1082-1087,Y-2014

33. Jasmin M., Vigneswaran T.,Fuzzy controller for error control of on - Chip communication,2017 International Conference on Algorithms, Methodology, Models and Applications in Emerging Technologies, ICAMMAET 2017,V-2017-January,I-,PP-1-5,Y-2017

\section{AUTHORS PROFILE}

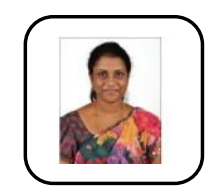

Magdalene Peter Assistant Professor, Department of MBA, Bharath Institute of Higher Education and Research, Tamilnadu, India

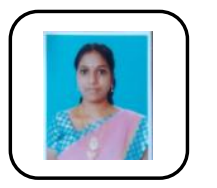

Fabiyola Kavitha Associate Professor ,Department of MBA, Bharath Institute of Higher Education and Research, Tamilnadu, India

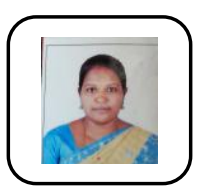

Geetha C Assistant Professor ,Department of CSE, Bharath Institute of Higher Education and Research, Tamilnadu, India 